\title{
Value Added Tax and Price Stability in Ethiopia: A Time Series Analysis
}

\author{
Isubalew Daba Ayana \\ Lecturer, Department of Economics, Wollega University, Nekemte, Ethiopia
}

\begin{abstract}
Value added tax (VAT), simply an indirect goods and services tax, which was implemented in Ethiopia starting from January, 1, 2003, is currently generating much debate especially with respect to its economic impact on aggregate level of prices. This study therefore, uses the quarterly time series data covering the period of 2004Q1 -2014Q4 to empirically examine the relationship between VAT and price level in Ethiopia. The data was sourced from NBE, ERCA, MOF, and EEA. Johansen Co-integration is adopted in this study as it allows one to explain the effect of the value added tax in isolation from other control variables in the study. The data is tested for unit root using the Augmented Dickey-Fuller (ADF) test and the Philips-Perron (PP) test, and the result shows that variables of the study are stationary in their first differences. The Johansen co integration test revealed that there is at least one co-integrating vector implying the existence of long run relationship between VAT and inflation in Ethiopia. The coefficient of estimated error correction model (ECM) revealed that the speed of adjustment for errors in the short run is 47.9 percent indicating high speed of adjustment. The coefficient of VAT in long run is 0.188578 , while it is 0.0051 in the short run enlightening that it influence price with the lower coefficient in short run. The explanatory variables accounted for 80.3 percent of the variations in inflation during the period of the study with the error term accounting for the remaining 19.7 percent. The finding of the study shows that VAT has positive and significant relationship with price in short run and long run. The positive significant impact of VAT on inflation is most likely due to the burden of the VAT on intermediate outputs. The policy implication is that well-being of the society needs to be taken into account in the process of public revenue generation. It follows that government should assure social desirability of VAT by conducting post implementation cost benefit analysis.
\end{abstract}

Keywords: VAT, Price Stability, Johansen Co-integration, Ethiopia

DOI: $10.7176 /$ RJFA/11-19-02

Publication date:October $31^{\text {st }} 2020$

\section{Introduction}

For any country in the world intensifying domestic revenue has a multi-dimensional purpose in all aspects to tackle the economic bottlenecks. One of the main mechanisms to ensure the economic development is tax revenue. Currently, Value added tax is an essential source of government budget in developing countries. For instance, the study recently conducted revealed that a one percent increases in the growth of net value added tax revenue causes $0.24 \%$ increase in the growth of nominal GDP in Pakistan (Hassan, 2015). In Latin America, VAT is highly recognized as the most important taxes for revenue generation and economic growth in Argentina, Brazil, Mexico, and Chile (Bacarreza et al. 2013).

Studies also reflect that Sub-Saharan African countries such as Cote d'Ivore, Benin Republic, Guinea, Kenya, Madagascar, Mauritius, Niger Republic, Senegal, Togo and Nigeria are reaping the fruit of VAT contribution in their total government tax revenues (Adereti et al, 2011). In Bangladesh, VAT becomes an option of government deficit financing in Bangladesh (Andrew et al, 2011). According to Musa and Sanusi (2013) VAT enhance the Nigerian economy positively. In addition, the study by Bakare (2013) found that VAT has a positive impact on total output growth in Nigeria. Moreover, Gatawa et al (2016) studied the effect of value added tax on economic growth and concluded that revenue from VAT continued to contribute more significantly to economic growth of Nigeria.

Ethiopia adopted VAT starting from January 1, 2003 when it was declared by proclamation no. 285/2002 making Ethiopia the late country that introduced VAT among African Union Member countries with exception of Angola which introduced it after three years in 2008 (Simon et al, 2013; Abate, 2011,FDRE,2002).

In Ethiopia, almost all scholars have the same view that VAT has significant contribution to the growth of the country. For instance, Alemu (2011), in his scholarly contribution, revealed that value added tax is clearly contributing to Ethiopian economic development and social spending. Jalata (2014) found that, in Ethiopia, the growth rate VAT revenue is $66.27 \%$ between the study period of 2003-2012 and the average ratio of VAT to GDP was $2.95 \%$ during the same period.

However, members of societies and various stake holders have been raising their reservation in the sense that VAT is taking a toll on the prices of their products. From the angle of economics, it is natural to expect that the price of goods subject to VAT to rise. However, beyond this natural expectation businesses are taking the advantage of existence of VAT to increase the price of goods and services arbitrarily without any economic reason. Before considering adoption of VAT, macroeconomic impact of it, especially on prices, output, income and 
consumption should be the concern of policy makers (Aruwa, 2008).

As matter of fact, there are few empirical works on the macroeconomic impact of VAT in developing countries especially on price level in general and in Ethiopian Context in particular. Marius and Alwell (2013) studied effect of VAT on price, and found that VAT has a strong positive significant effect on prices. Ajakaiye (1999) studied the impact of VAT on key sectors macroeconomic aggregates using Computable General Equilibrium (CGE) model for the Nigerian economy, and concluded that VAT is more deleterious when viewed as a cost. In addition, Olatunji (2013) studied VAT and inflation from 1990 to 2003 for economy of Nigeria and found that VAT has not affected the increase or decrease in inflation rate in Nigeria for the period under investigation.

The contribution of these scholars about the real context of Ethiopia, with exception of Jalata (2014) and Alemu (2011), who focused on VAT contribution to GDP, is unnoticed as there is no wide-ranging empirical work steered on the impact of VAT on price stability in Ethiopia. In other words, the study of these previous authors focused on the contribution of VAT to economic growth. Specially, in developing countries like Ethiopia such studies are very important in identifying the sources of price rise to combat the adverse effect of the value added tax on the general price. Thus, this study focuses on empirical investigation of the relationship between VAT and price level in Ethiopia for the period of 2004 Q1 to 2014 Q4.

\section{Literatures Review}

Value added tax, often named as tax on consumption, has been defined from different angles by several scholars. Very recently Musa and Sanusi (2013) defined VAT as cost charged on finished goods and services less a cost charged for inputs of production such as raw materials. The definition of VAT by Bhartia (2009) considers value added tax as a tax on the values added not tax on the value of the commodity sold. This definition explains VAT as a difference between the value of input and gross value, and that seller is responsible to pay the tax.

Adesola (2000) defined VAT as consumer tax since it is the sum of wage and profit tax and levied on consumer before selling the good or service. The definition given by Umeora (2013) focuses on that VAT is a tax on estimated market value added to a product and explained that the additions are to the final customers.

There are plenty of empirical works conducted about the impact of VAT on economic growth around the globe. For instance, Michael \& Ben (2007) studied the causes and consequences of the spread of value added tax (VAT) in effort of developing the model of VAT adoption. Their paper observed that VAT has significant and mixed impact on economic growth. A panel study approach was adopted. The data covered 143 countries for 25 years were used in the analysis. The result revealed that VAT has mixed but significant impact on revenue generation. It also revealed that there is a difference in the gain from VAT among countries.

Secondly, Asgowa and Nkolika (2013) carried out a work on value added tax on investment growth in Nigeria with the objective of examining the impact of VAT on investment growth. Their work employed multiple regression analysis. The study used time series data on variables such as investment, government expenditure, real exchange rate, real interest rate and trade openness, and found that value added tax has significant effect on investment growth in the country. The policy recommendation of the study was that government should be apparent honest to improve the way of Value added tax collection.

Thirdly, the work of Ezeji and Peter (2014) examined the impact of value added tax on economic growth. Their analysis was conducted using Engle and Granger co integration technique on annual data sample covering 1994 to 2012. Econometric analysis conducted has shown that VAT has significant and positive effect on economic growth. The result of the technique reveals that relationship between VAT and GDP is absent both in short and long run in Nigeria.

Shelomentsev and Zhan-Ming (2019) carried out a work on effect of value added tax on economic growth in Kenyan economy. The casual study from 1973 to 2010 was adopted in the paper. The study used gross domestic product, consumer prices as measured by consumer price indexes, and employment as measured by the unemployment rate as explanatory variables and VAT rates as explained Variable. The data analysis method adopted in the study was the time varying regression models, Poisson and negative binomial regression models. The study observed that there is a significant negative relationship between GDP and VAT rates. The study recommended that the concerned body (Kenyan government) should work hard to maintain positive relationship between VAT rates and economic growth.

The empirical investigation of Izedonmi and Okunbor, (2014), shows that VAT revenue is an important determinant of economic growth for the study period of 1994-2010 in Nigeria. The paper used time series data analyzed using Cobb-Douglas regression model. Their study further explained that VAT revenue has statistically insignificant but positive effects on economic growth indicating deprived management of value added tax in the country.

Okoye and Gbegi, (2013), who investigated the contribution of effective value added tax on economic development using Pearson product movement correlation coefficient and the Student's T-test to investigate the hypotheses, observed that VAT is contributing significantly to GDP, and thus considered as a bedrock of wealth 
creation and economic development in Nigeria.

Ilaboya and Mgbame(2012), in their work on the relationship between indirect tax and economic growth, using Engel-Granger two step procedure method to test, found that the relationship between indirect tax and economic growth is negative and at the same time insignificant. The study used Autoregressive Distributed Lag (ARDL) to correct the disturbance between short and long run as the ratio of total indirect tax ratio is appeared to be negative coefficient. The finding of this paper is probably the first as far as the Nigerian economy is concerned.

Asgowa and Nkolika (2013) investigated the impact of VAT on the growth of investment with the aid of multiple regression analysis. From time series analysis they observed that VAT affects the growth of investment in positive way. According to them VAT should have single influence on consumer prices. This should also be consistent with whatever the level of value added tax rate and stages of VAT collection.

According to the study conducted by Ajakaiye (1999), when VAT is treated as additional cost by VAT registered organizations, in growing economies, high risk of VAT sustainability exists. Using computable general equilibrium analysis to empirically investigate aggregated level consequence of VAT on essential sectors of Nigerian economy, his paper found that a 5\% VAT rate results in $12 \%$ percent swell in general price index. His study also concluded that the way VAT registered businesses consider VAT determines its effect on economy.

Maries and Alwell (2013) investigated the effect of VAT on price stability using partial equilibrium analysis. Empirical results of their paper confirm that between the periods of 1994- 2010 VAT significantly influenced the price level as observed from multiple regression adopted in the model of study. In their paper, they underlined that in spite of its significance as source of revenue, VAT is not free from inflationary outcome. In general, their study concluded that the rise in price due to the VAT can create instability to the economy of Nigeria. They preferred partial equilibrium as it provides the advantage of forecasting well irrespective of sample size both in short and long run.

\section{Methods and Materials}

\subsection{Sources of Data}

This research is inferential in nature and requires the collection of quantitative data. Thus, Quarterly time series data for the period of 2004Q1-2014Q4 is used in the study. The data are sourced from currently ministry of finance (MOF), Revenue and Custom Authorities (ERCA), Central Statistical Authorities (CSA), Ethiopian Economic Association (EEA) and National Bank of Ethiopia (NBE).

\subsection{Variables of the Study}

In order to attain its objectives, the study came across the variables that used in the study of Marius and Alwell (2013) which used inflation as explanatory variable, and fiscal deficit, growth rate of money supply, real interest rate and real exchange rate as explanatory variables. The Variables in this study were adopted from their study by dropping real interest rate from independent variables and, adding import as an explanatory variable. In addition to this, real exchange rate is dropped and real effective exchange rate is added in the process of explanatory variables adoption. Now the investigator has full confidence about the variables of the study.

Therefore, the dependent variable of the research was inflation measured by consumer price index (CPI) which is the most commonly used index in Ethiopia. Explanatory variables were Fiscal deficit (FDFCT), Broad money supply (BRDM), Real Effective Exchange rate (REER), Value added tax (VAT) and Import (IMPT). Broad money supply was adopted as the concept of money supply and its growth rates was calculated as the ratio of the amount by which current period level of money supply differs from that of proceeding level. The variables are in the form of natural logarithm $(\log )$ for the purpose of maintaining linearity and normality in the model. The detail description of the variables is given in the table 1 below.

Table1: Description of the variables in the study

\begin{tabular}{|l|l|}
\hline Variables & \multicolumn{1}{|c|}{ Description of Variables } \\
\hline LogCPI & The general Ethiopian Consumer Price Index in log form. \\
\hline LogFDFCT & Fiscal Deficit in log Form \\
\hline Log REER & Real effective Exchange rate of ETB to \$ in log form \\
\hline Log VAT & The Value Added tax Revenue in log Form \\
\hline Log BRDM & Broad money(M2) simply money supply in log form \\
\hline Log IMPT & Import of goods and services in log form \\
\hline
\end{tabular}

\subsection{Specification of the Model}

Scholars have tried to specify different models to investigate the impact of VAT on price level in different times. For instance, Fatukasi (2005) conducted his study by combining the structuralist, monetarist and fiscalist approaches to inflation modeling. In addition, Marius and Alwell (2013) favored the partial equilibrium analysis as it allows one to clarify the effect of VAT in isolation from those of other control variables included in the model. Towards achievement of its objective, this study adopted the model developed by Marius and Alwell (2013) since 
it has the advantage of providing the short and long-run impacts of the variables included in the model simultaneously. However, this study has improvement upon them in which as it added more explanatory variables and incorporated explanatory variables from the context of Ethiopia. Moreover, model in this study considers the year between 2004Q1- 2014Q4 to updates the analysis and it provides the information about impact of value added tax on price stability from in Ethiopian. Thus, adjusted variables based on the objectives of the study are CPI, FDFCT, REER, and VAT, BRDM and IPMT.

Accordingly, non-stochastic relationship established is as follows:

$\mathrm{CPI}=(\mathrm{FDFCT}, \mathrm{REER}, \mathrm{VAT}, \mathrm{BRDM}, \mathrm{IMPT})$

Finally working stochastic model is:

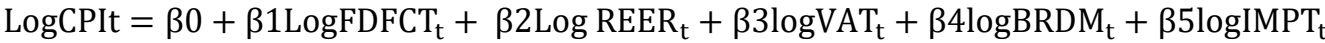

$$
\begin{aligned}
& + \text { st } \ldots \ldots \ldots \ldots \ldots \ldots \ldots \ldots \ldots \ldots \ldots \ldots \text { (3.1) }
\end{aligned}
$$

Where, $\mathbf{L o g}$ stands for the natural logarithm, $\mathbf{S}$ for the error term, $\mathbf{t}$ for the time parameter, $\boldsymbol{\beta 1}, \boldsymbol{\beta 2}, \boldsymbol{\beta 3}, \boldsymbol{\beta 4}$, and $\boldsymbol{\beta}_{5}$ are the elasticity of VAT, fiscal deficits (FDFCT), real effective exchange rate (REER), money supply (BRDM) and import (IMPT).

The priori expectation of the model is that all independent variables; FDFCT, BRDM, REER, VAT and IMPT have positive relationship with the consumer price index (CPI). This means, the coefficients of all explanatory variables or elasticity is greater than zero. It follows that $\beta 1, \beta 2, \beta 3, \beta 4, \beta 5>0$.

Data analysis was conducted using e-view 7.1 econometrics software package. The software is preferred due to its convenience and better performance in the analysis of time series data.

\section{Results and Discussions}

\subsection{Unit Root Test}

This paper employed the two most popular way of unit root tests; ADF and PP. ADF is an augmented version of the Dickey fuller for a larger and more complicated set of time series models. It has the advantage of providing unit root result with the lagged value of regression.

Equation (4.1) consists of ADF model without the intercept and constant while equation (4.2) is the model with constant. Equation (4.3) consists of both trend and intercept.

$$
\begin{array}{r}
\Delta \mathrm{Y}_{\mathrm{t}}=\delta \alpha y_{t-1}+\mathrm{a}_{\mathrm{i}}+\mu_{\mathrm{t}} \ldots \ldots \ldots \ldots \ldots \ldots \ldots \ldots \ldots \ldots \ldots \ldots \ldots \\
\Delta Y_{t}=\alpha_{o}+\alpha Y_{t}-1+\sum_{i-1}^{n} \emptyset i \Delta \mathrm{Y}_{t-i}+\omega_{\mathrm{t}} \ldots \ldots \\
\Delta Y_{t}=a_{o}+\alpha_{1} Y_{t-1}+\alpha_{2 t} \sum_{i=1}^{n} \emptyset \mathrm{i} \Delta \mathrm{Y}_{\mathrm{t}-1}+\omega_{\mathrm{t}}
\end{array}
$$

$\omega t=$ represents stochastic variable while

$Y t=$ represents time series variables in the study

In ADF unit root test, the null hypothesis (H0) is that a time series data contains a unit-root (non-stationary) and the alternative hypothesis (H1) is that the variable is stationary. If null hypothesis in augmented Dickey fuller is rejected, it implies that variables are stationary (there is no unit root). It follows that variables are ready to be used in the econometric analysis. If the null hypothesis is failed to be rejected it means that variables cannot be

\begin{tabular}{|c|c|c|c|c|c|c|}
\hline Variables & Integrating & ADF test stats & $\begin{array}{l}\text { Test } \\
\text { Critical } \\
\text { value }\end{array}$ & $\begin{array}{l}\text { Probability } \\
\text { value }\end{array}$ & $\begin{array}{l}\text { Included in } \\
\text { the equation }\end{array}$ & Inference \\
\hline \multirow[t]{2}{*}{ LOGCPI } & Level & $-1.916036 * *$ & -3.536601 & 0.6261 & $\begin{array}{l}\text { Constant and } \\
\text { trend }\end{array}$ & $\begin{array}{l}\text { Non } \\
\text { stationary }\end{array}$ \\
\hline & $\begin{array}{l}\text { First } \\
\text { Difference }\end{array}$ & $-6.345536^{* *}$ & -3.520787 & 0.0000 & $\begin{array}{l}\text { Constant and } \\
\text { trend }\end{array}$ & Stationary \\
\hline \multirow[t]{2}{*}{ LOGFDFCT } & Level & $-2.031483 * *$ & -3.518090 & 0.5680 & $\begin{array}{l}\text { Constant and } \\
\text { trend }\end{array}$ & $\begin{array}{l}\text { Non } \\
\text { stationary }\end{array}$ \\
\hline & $\begin{array}{l}\text { First } \\
\text { Difference }\end{array}$ & $-6.300484 * *$ & -3.520787 & 0.0000 & $\begin{array}{l}\text { Constant and } \\
\text { trend }\end{array}$ & Stationary \\
\hline \multirow[t]{2}{*}{ LOGREER } & Level & $-2.157372 * *$ & -3.518090 & 0.5003 & $\begin{array}{l}\text { Constant and } \\
\text { trend }\end{array}$ & $\begin{array}{l}\text { Non } \\
\text { stationary }\end{array}$ \\
\hline & $\begin{array}{l}\text { First } \\
\text { Difference }\end{array}$ & $-4.448414 * *$ & -3.448414 & 0.0000 & $\begin{array}{l}\text { Constant and } \\
\text { trend }\end{array}$ & Stationary \\
\hline
\end{tabular}
used in the model analysis. Thus, we go further until the variables are ready to be used in the analysis since stationary data is must in the econometric work (Dickey and Fuller, 1979, Gujarati and Porter, 2009).

Table 2: ADF stationary tests at level and first difference 


\begin{tabular}{|c|c|c|c|c|c|c|}
\hline Variables & Integrating & ADF test stats & $\begin{array}{l}\text { Test } \\
\text { Critical } \\
\text { value }\end{array}$ & $\begin{array}{l}\text { Probability } \\
\text { value }\end{array}$ & $\begin{array}{l}\text { Included in } \\
\text { the equation }\end{array}$ & Inference \\
\hline \multirow[t]{2}{*}{ LOGVAT } & Level & $-2.032045^{* *}$ & -3.518090 & 0.5677 & $\begin{array}{l}\text { Constant and } \\
\text { trend }\end{array}$ & $\begin{array}{l}\text { Non } \\
\text { stationary }\end{array}$ \\
\hline & $\begin{array}{l}\text { First } \\
\text { Difference }\end{array}$ & $-6.499152 * *$ & -3.520787 & 0.0000 & $\begin{array}{l}\text { Constant and } \\
\text { trend }\end{array}$ & Stationary \\
\hline \multirow[t]{2}{*}{ LOGBRDM } & Level & $-1.437692 * *$ & -3.518090 & 0.8352 & $\begin{array}{l}\text { Constant and } \\
\text { trend }\end{array}$ & $\begin{array}{l}\text { Non } \\
\text { stationary }\end{array}$ \\
\hline & $\begin{array}{l}\text { First } \\
\text { Difference }\end{array}$ & $-5.832347 * *$ & -3.520787 & 0.0001 & $\begin{array}{l}\text { Constant and } \\
\text { trend }\end{array}$ & Stationary \\
\hline \multirow[t]{2}{*}{ LOGIMPT } & Level & $-1.366166 * *$ & -3.518090 & 0.8596 & $\begin{array}{l}\text { Constant and } \\
\text { trend }\end{array}$ & $\begin{array}{l}\text { Non } \\
\text { stationary }\end{array}$ \\
\hline & $\begin{array}{l}\text { First } \\
\text { Difference }\end{array}$ & $-6.797921 * *$ & -3.520787 & 0.0000 & $\begin{array}{l}\text { Constant and } \\
\text { trend }\end{array}$ & Stationary \\
\hline
\end{tabular}

$*, * * *$ and $*$ denotes $5 \%, 10 \%$ and $1 \%$ level of significance respectively, Source: Estimate results from e-views 7.1.

Table 2 shows that all variables are not stationary at their level but stationary at their first differencing under Augmented Dickey fuller unit root test and became significant at five percent significant level. In this study, it is planned to cross check the results of ADF using the Phillips-Perron unit root test to capture the criticisms of ADF test.

The Philips- Perron (PP) unit root test, which gives robust estimates especially in the presence of structural break (Maddala, 1992) is given as:

$$
Y t=\mu o+\mu 1\left(\mathrm{t}-\frac{\mathrm{T}}{2}\right)+\alpha o Y \mathrm{t}-1+\sum_{\mathrm{i}=1}^{\mathrm{m}} \omega \Delta \mathrm{Yt}-1+\mathrm{ut}
$$

Where, $\mathrm{m}$ is the lag length of the PP unit root test and

$\mathrm{T}$ is the number of observations used in the PP unit root test

According to Enders (1995) PP unit root test is proposed by Phillips and Perron unit root test is an alternative method to the ADF. The PP test advocated the inclusion of nonparametric adjustment to the model to obtain error term instead of adding additional lag as the case of ADF. Moreover, Phillips Perron unit root test is distributed heterogeneously and widely used as way of checking the result of ADF unit root test result. It also provide confidence to the researcher if the two ways; ADF and PP gives the same result and it will be safe and more secured to conclude the about the presence or absence of the Unit root in the variables of the study. Therefore, the null and alternative hypothesis under both ADF and PP are the same. The null hypothesis (H0) is that the data is unit root (non-stationary) while the alternative hypothesis (H1) the presence of stationary. The rejection of null hypothesis shows that the data is ready to be used in the analysis.

Table 3: Philips-Perron stationary tests at level and first difference

\begin{tabular}{|c|c|c|c|c|c|c|}
\hline Variables & Integrating & PP test stats & $\begin{array}{l}\text { Test Critical } \\
\text { value }\end{array}$ & $\begin{array}{l}\text { Probabil } \\
\text { ity value }\end{array}$ & $\begin{array}{l}\text { Included in the } \\
\text { equation }\end{array}$ & Inference \\
\hline \multirow[t]{2}{*}{ LOGCPI } & Level & $-1.699229 *$ & -3.518090 & 0.7344 & $\begin{array}{l}\text { Constant and } \\
\text { trend }\end{array}$ & $\begin{array}{l}\text { Non } \\
\text { stationary }\end{array}$ \\
\hline & $\begin{array}{l}\text { First } \\
\text { Difference }\end{array}$ & -6.345068 & -3.520787 & 0.0000 & $\begin{array}{l}\text { Constant and } \\
\text { trend }\end{array}$ & Stationary \\
\hline \multirow[t]{2}{*}{ LOGFDFCT } & Level & $-2.167526^{*}$ & -3.518090 & 0.8645 & $\begin{array}{l}\text { Constant and } \\
\text { trend }\end{array}$ & $\begin{array}{l}\text { Non } \\
\text { stationary }\end{array}$ \\
\hline & $\begin{array}{l}\text { First } \\
\text { Difference }\end{array}$ & -6.300336 & -3.520787 & 0.0000 & $\begin{array}{l}\text { Constant and } \\
\text { trend }\end{array}$ & Stationary \\
\hline \multirow[t]{2}{*}{ LOGREER } & Level & $-2.334652 *$ & -3.518090 & 0.4070 & $\begin{array}{l}\text { Constant and } \\
\text { trend }\end{array}$ & $\begin{array}{l}\text { Non } \\
\text { stationary }\end{array}$ \\
\hline & $\begin{array}{l}\text { First } \\
\text { Difference }\end{array}$ & $-4.448414 *$ & -3.520787 & 0.0000 & $\begin{array}{l}\text { Constant } \\
\text { trend }\end{array}$ & Stationary \\
\hline \multirow[t]{2}{*}{ LOGVAT } & Level & $-2.142070^{*}$ & -3.518090 & 0.5085 & $\begin{array}{l}\text { Constant and } \\
\text { trend }\end{array}$ & $\begin{array}{l}\text { Non } \\
\text { stationary }\end{array}$ \\
\hline & $\begin{array}{l}\text { First } \\
\text { Difference }\end{array}$ & -6.499159 & -3.520787 & 0.0000 & $\begin{array}{l}\text { Constant } \\
\text { trend }\end{array}$ & Stationary \\
\hline LOGBRDM & Level & $-1.619104 *$ & -3.518090 & 0.7688 & $\begin{array}{l}\text { Constant and } \\
\text { trend }\end{array}$ & $\begin{array}{l}\text { Non } \\
\text { stationary }\end{array}$ \\
\hline
\end{tabular}




\begin{tabular}{|l|l|l|l|l|l|l|}
\hline Variables & Integrating & PP test stats & $\begin{array}{l}\text { Test Critical } \\
\text { value }\end{array}$ & $\begin{array}{l}\text { Probabil } \\
\text { ity value }\end{array}$ & $\begin{array}{l}\text { Included in the } \\
\text { equation }\end{array}$ & Inference \\
\hline & $\begin{array}{l}\text { First } \\
\text { Difference }\end{array}$ & -5.832347 & -3.520787 & 0.0001 & $\begin{array}{l}\text { Constant and } \\
\text { trend }\end{array}$ & Stationary \\
\hline LOGIMPT & Level & $-1.310009^{*}$ & -3.518090 & 0.8721 & $\begin{array}{l}\text { Constant and } \\
\text { trend }\end{array}$ & $\begin{array}{l}\text { Non } \\
\text { stationary }\end{array}$ \\
\cline { 2 - 6 } & $\begin{array}{l}\text { First } \\
\text { Difference }\end{array}$ & $-7.519263^{*}$ & -3.520787 & 0.0000 & $\begin{array}{l}\text { Constant and } \\
\text { trend }\end{array}$ & Stationary \\
\hline
\end{tabular}

Source: Own estimation, ${ }^{*}, * *$ and $*$ denotes $5 \%, 10 \%$ and $1 \%$ level of significance respectively, Source: Estimate results from e-view 7.1

PP unit root test shows that the data is stationary. That means the ADF and PP unit root test results are now the same. Since the main objective here is getting stationary time series for analysis, the variables are differenced and when Phillips-Perron unit root test is applied on the first difference of the variables, each series become stationary. All variables become significant at $5 \%$ significance level.

Generally, the conducted unit root tests reveal that variables are non-stationary at level and have to be differenced to achieve stationary of data in the analysis. It follows that data are stationary at their first differencing. The reality of this is clearly confirmed by both ADF and PP unit root tests. In other words, both tests checked that variables have unit root at level but stationary at their first difference. Thus, it is now safe and sufficient to conclude that variables are stationary at their first difference and hence I (1). Due to the fact that data are confirmed for their stationary, the Johansen test for co integration does not suffer from mixed order of integration during the analysis. Table 4: Lag Length Selection test

VAR Lag Order Selection Criteria

Endogenous variables: LOG_CPI LOG_FDFCT LOG_REER LOG_VAT LOGBRDM

LOGIMPT

Exogenous variables: $\mathrm{C}$

Date: $03 / 31 / 16$ Time: $13: 35$

Sample: 2004Q1 2014Q4

Included observations: 41

\begin{tabular}{|c|c|c|c|c|c|c|}
\hline \hline Lag & LogL & LR & FPE & AIC & SC & HQ \\
\hline \hline 0 & 134.7432 & NA & $7.55 \mathrm{e}-11$ & -6.280156 & -6.029390 & -6.188841 \\
1 & 298.0282 & 270.8141 & $1.55 \mathrm{e}-13$ & -12.48918 & $-10.73381^{*}$ & -11.84997 \\
2 & 346.9856 & $66.86865^{*}$ & $9.24 \mathrm{e}-14^{*}$ & $-13.12125^{*}$ & -9.861281 & $-11.93415^{*}$ \\
3 & 380.4110 & 35.87123 & $1.45 \mathrm{e}-13$ & -12.99566 & -8.231095 & -11.26067 \\
\hline \hline
\end{tabular}

* indicates lag order selected by the criterion

LR: sequential modified LR test statistic (each test at 5\% level)

FPE: Final prediction error

AIC: Akaike information criterion

SC: Schwarz information criterion

HQ: Hanna-Quinn information criterion

Source: Estimate results from e-view 7.1

As it is depicted by table 4, it is observed that the lag order suggested by Akaike information criterion is 2 , and it is supported by majority of other selection criteria such as Hannan-Quinn information criterion (HQ), Final prediction error (FPE), and sequential modified LR test statistic (LR) while only Schwarz information criterion selected lag 1 which is out of majority's view. Therefore, lag 2 is accepted for the analysis. In order to have high confidence about the lag length selected in this study the VAR lag exclusion test is conducted using Wald tests and the result is presented in table 5. 
Table 5: Lag Exclusion Wald Test result

\section{VAR Lag Exclusion Wald Tests}

Date: 05/07/16 Time: 10:21

Sample: 2004Q1 2014Q4

Included observations: 41

Chi-squared test statistics for lag exclusion:

\begin{tabular}{cccccccc}
\hline \hline & LOG_CPI & LOG_FDFCT & LOG_REER & LOG_VAT & LOGBRDM & LOGIMPT & Joint \\
\hline \hline Lag 1 & 84.52754 & 20.70662 & 57.62885 & 6.150763 & 3.882701 & 8.824814 & 210.5120 \\
& {$[4.44 \mathrm{e}-16]$} & {$[0.052071]$} & {$[1.36 \mathrm{e}-10]$} & {$[0.406515]$} & {$[0.692547]$} & {$[0.183673]$} & {$[0.178043]$} \\
Lag 2 & 22.60845 & 10.55215 & 13.70524 & 7.649428 & 7.442420 & 7.201150 & 85.99354 \\
& {$[0.000039]$} & {$[0.003244]$} & {$[0.000008]$} & {$[0.000928]$} & {$[0.000861]$} & {$[0.006828]$} & {$[0.000000]$} \\
Lag 3 & 5.290998 & 7.472325 & 6.811027 & 6.341595 & 5.784730 & 3.251305 & 47.39851 \\
& {$[0.507068]$} & {$[0.279364]$} & {$[0.338678]$} & {$[0.386032]$} & {$[0.447732]$} & {$[0.776708]$} & {$[0.496824]$} \\
\hline \hline Df & 6 & 6 & 6 & 6 & 6 & 6 & 36 \\
\hline \hline
\end{tabular}

Source: Estimate results from e-view 7.1

The null hypothesis of Wald test is that the joint coefficients of lags are zero. Rejection of null hypothesis means that the corresponding lag should be included in the study and fail to reject the joint null hypothesis leads to the exclusion of the lag from the study. Accordingly, the results in Table 4 show that we cannot reject the joint hypothesis that the coefficients of lags 1 and 3 are all equal to zero because the joint p-value of both lags is above $5 \%$. For lag 2 however, we can reject the null hypothesis implying that the coefficient is different from zero and should be used in the study.

\subsection{Analysis of Co Integration: The Johansen Test for Co Integration}

In this study a VAR model based on co integration as suggested by Johansen (1995) is employed. The main reason why the Johansen co integration test is preferred in the study is that it performs better in the multivariate time series and it also enable to conduct analysis based on vector auto regression.

Johansen starts his methodology from VAR of order $\mathrm{P}$ given as:

$$
Y_{t}=K+\Delta \mathrm{Y}_{\mathrm{t}-1}+\cdots+\Delta \mathrm{PY}_{\mathrm{t}-\mathrm{p}}+u_{t}
$$

Where, $Y_{t}$ represent an $\mathrm{nx} 1$ integrated vectors and the integrated vectors are usually order of one.

Thus, VAR model, to estimate at first difference can be written as

$$
\Delta Y_{t}=K=B+\Delta \mathrm{Y}_{\mathrm{t}-1}+\sum_{\mathrm{i}-1}^{\mathrm{p}-1} 1+\mathrm{u}_{\mathrm{t}}
$$

In this case, $P=\sum_{\mathrm{i}-1}^{\mathrm{p}} \mathrm{Ai}-1$ and $\prod i=a_{0}+\sum_{j=i+1}^{n} A j$

Trace Test Statistics: This is a maximum likely hood ratio identified by Johansen (1988). In the trace test of Johansen methodology the trace statistics will be small when there are characteristics roots that are very closer to zero and the null hypothesis is that the number of co integrating vector is less than or equal to co integrating relations. However, the presence of at least one co- integration rejects the null hypothesis and convinces (reflects) the presence of long run relationships among variables.

The methodology developed by Johansen (1988) identified here under in the following form

$$
\pi \text { trace }=-T \sum_{i=r+1}^{K} \log (1-\gamma 1)
$$

Where: $\gamma$ represent the $i^{\text {th }}$ largest Eigen value of matrix Пand $\mathrm{T}$ shows the number of observations included in the estimation.

The Maximum Eigen Value Statistics: This is another test developed by Johansen (1988) assuming the null hypothesis of exactly $\mathbf{r}$ co integrating relations against the alternative of $r+1$ co integrating relations and the test is given as:

Where,

$$
\tau \max =-T \log (1-\gamma r+1)
$$


$-\gamma r+1$, represent largest squared Eigen value of $\mathrm{r}+1$.

It is possible to say that difference between trace statistics and maximum Eigen value of Johansen (1988) lies around their null and alternative hypothesis. The former assume the null hypothesis of $r=0$ is tested against the alternative of $r+1$ co integrating vectors while the later assumes exactly $r$ co integrating relations against the alternative of $r+1$ co integrating relations.

Table 6: The Trace Statistics Result of Johansen Test of Co integration

\begin{tabular}{|c|c|c|c|c|}
\hline \multicolumn{5}{|c|}{ Unrestricted Co integration Rank Test (Trace) } \\
\hline $\begin{array}{l}\text { Hypothesized } \\
\text { No. of CE(s) }\end{array}$ & Eigen value & $\begin{array}{c}\text { Trace } \\
\text { Statistic }\end{array}$ & $\begin{array}{c}0.05 \\
\text { Critical Value }\end{array}$ & Prob.** \\
\hline $\begin{array}{c}\text { None } * \\
\text { At most } 1 \\
\text { At most } 2 \\
\text { At most } 3 \\
\text { At most } 4 \\
\text { At most } 5\end{array}$ & $\begin{array}{l}0.769646 \\
0.519108 \\
0.452375 \\
0.233458 \\
0.082051 \\
0.010230\end{array}$ & $\begin{array}{l}129.7313 \\
69.53764 \\
39.52099 \\
14.83221 \\
3.931733 \\
0.421596\end{array}$ & $\begin{array}{l}95.75366 \\
69.81889 \\
47.85613 \\
29.79707 \\
15.49471 \\
3.841466\end{array}$ & $\begin{array}{l}0.0000 \\
0.0526 \\
0.2401 \\
0.7908 \\
0.9090 \\
0.5161\end{array}$ \\
\hline \multicolumn{5}{|l|}{ Notes: } \\
\hline \multicolumn{5}{|c|}{ Trace test indicates 1 co integrating eqn (s) at the 0.05 level } \\
\hline \multicolumn{5}{|c|}{$*$ denotes rejection of the hypothesis at the 0.05 level } \\
\hline
\end{tabular}

Source: Estimate results from e-view 7.1

Table 7: The Maximum Eigen Value Result of Johansen Co Integration

Unrestricted Co integration Rank Test( Maximum Eigen Value)

\begin{tabular}{c|c|c|cc}
\hline \hline $\begin{array}{c}\text { Hypothesized } \\
\text { No. of CE(s) }\end{array}$ & Eigenvalue & $\begin{array}{c}\text { Max-Eigen } \\
\text { Statistic }\end{array}$ & $\begin{array}{c}0.05 \\
\text { Critical Value }\end{array}$ & Prob.** $^{* *}$ \\
\hline \hline None $*$ & 0.769646 & 60.19362 & 40.07757 & 0.0001 \\
At most 1 & 0.519108 & 30.01665 & 33.87687 & 0.1350 \\
At most 2 & 0.452375 & 24.68878 & 27.58434 & 0.1124 \\
At most 3 & 0.233458 & 10.90047 & 21.13162 & 0.6572 \\
At most 4 & 0.082051 & 3.510136 & 14.26460 & 0.9071 \\
At most 5 & 0.010230 & 0.421596 & 3.841466 & 0.5161 \\
\hline \hline
\end{tabular}

Max-eigenvalue test indicates 1 co integrating eqn(s) at the 0.05 level

$*$ denotes rejection of the hypothesis at the 0.05 level

**MacKinnon-Haug-Michelis (1999) p-values

Source: Own Computation from e-View 7.1

Tables 6 and 7 show the results of an unrestricted co integration rank tests Trace and Maximum Eigen value respectively. The results from the above tables reveal that the null hypotheses for none, at most 2, at most 3 , at most 4 and at most 5 co integrating relationship among the variables were rejected at 5 percent significant level, indicating the existence of at most 1 co integrating relationships among the variables.

4.3 Long Run Relationship between VAT and Inflation in Ethiopia

Table 8: The Normalized Co integration Coefficients (1 Co-integrated equation)

\begin{tabular}{|l|l|l|l|l|l|c|}
\hline LOGCPI & LOGFDFCT & LOGREER & LOGVAT & LOGBRDM & LOGIMPT & C \\
\hline 1.0000 & $0.037383^{* * *}$ & $0.2810350^{* * *}$ & $0.188578^{* * *}$ & $0.574615^{* * *}$ & $0.23970 * * *$ & 1.672192 \\
& $(0.02165)$ & $(0.06122)$ & $(0.03366)$ & $(0.12683)$ & $(0.06543)$ & $(0.076149)$ \\
& {$[0.0356]$} & {$[0.0000]$} & {$[0.0000]$} & {$[0.0000]$} & {$[0.0000]$} & {$[0.0000]$} \\
\hline
\end{tabular}

Source: Own Computation from e-View 7.1

Note: **and $* * *$ represent the significance of the coefficient at $5 \%$ and $10 \%$ level respectively. Values in [] shows the P-values and the values in () shows the standard errors. $C$ is constant.

One of the good sides of Johansen test for co integration is that it provides the normalized coefficients of variables in the long run. Accordingly, table 4.8 shows that long run effect of VAT on the aggregate consumer price (inflation) is positive and also significant at $1 \%$ significance level for the period under examination i.e. from the first quarter of 2004 to the final quarter of 2014. Specifically, a 1\% increase in VAT revenue has leads to 
$0.188578 \%$ during the period. This result confirms the positive relationship between VAT revenue and aggregate price level.

The positive sign of VAT was the one expected and it is in line of the priori expectation. The positive and significant relationship between VAT and price level in Ethiopia most likely be attributed to VAT charges on intermediate outputs and other materials. It may also be because of the fact that the final result of a given production process could be the input of yet another production process, whose outputs are successively subject to value added tax in Ethiopia. When this situation is observed in an economy, multiple value added tax burdens become the norm. As a result, it forces increases in prices of goods and services for the consumers as it push up the consumer price index.

When it is observed from the producer's point of view, the value added tax is the burden of producers whose inputs are intermediate outputs. This amounts of tax on value added increases cost of production for these producers. The finding of this study is similar with that of Maries and Alwell (2013), who found the positive and significant relationship between VAT and price level using OLS regression. The finding of this study also coincide with the finding of Ajakaiye (1999), who revealed that VAT is deleterious (push prices up) when considered and cascaded as cost using a computable general equilibrium analysis. Thus, it is adequate to conclude that the Variable of interest, VAT, exerts an upward pressure on price levels in Ethiopia within the limits of period studied. In other words, it is possible to conclude that the relationship between VAT and price level in Ethiopia is positive and significant in the long run.

On the other hand, the relationship between inflation and other control variables is discussed as here under follows. The estimated coefficient of fiscal deficit is found to be positive. This is the expected sign and it is in line with the priori expectation. The empirical evidence of the current study shows that when fiscal deficit increases by $0.037383 \%$, the inflation is pushed up by $1 \%$ in Ethiopia for the period under investigation. Despite the expected positive sign, the relationship between inflation (CPI) and fiscal deficit (FDFCT) remain weak when observed from elasticity point of view when compared to other variables used in the study. The reason behind this may goes to the issue of government revenue and expenditure. It obvious that fiscal deficit happen when government expenditure is above the government revenue.

When developing countries like Ethiopia face fiscal deficit, they search the option of getting revenue such as grants and donations. When they get donations they spend on public infrastructure in the way it cannot significantly affect inflation level of a country in the long run. The finding of this study is similar with finding of Makochekanwa (2011), who found positive but insignificant relationship between fiscal deficit and inflation for Zimbabwe since study observed that massive monetization of fiscal deficit resulted in inflationary effects for Zimbabwean economy. The empirical finding of this thesis also coincide with Ezeabasili (2012), who found insignificant positive relationship between fiscal deficit and inflation using structural analysis and co integration technique for the economy of Nigeria. Everton et al. (2013) also observed that contribution of fiscal deficit is positive and insignificant for Nigeria.

The coefficient of broad money (BRDM) is found to be positive and significant at $1 \%$ level of significance in the long run. The coefficient is observed as 0.574615 indicating that a $1 \%$ increase in the level of money supply leads to $0.574615 \%$ rise in inflation for the study period in Ethiopia. The positive and significant relationship is expected and found to be correct as expected. The typical explanation for this is that broad money is the most power full component of money supply. The finding of this study is similar to Akinbobola (2012), who found positive relationship between money supply and inflation. For Ethiopia, Denbel et al (2016) found the positive and significant relationship that supports monetarists between money supply and aggregate price level (inflation) in the long run.

With regard to import (IMPT) variable, it is observed that the coefficient is in line with the priori expectation. The elasticity coefficient shows that inflation increase by $1 \%$ when the volume of import rise by $0.23970 \%$. The reason behind positive and significant effect of volume of import is attributed to large volume of commodities imported from abroad as manufacturing is at its infant in Ethiopia. It is obvious that Ethiopia imports goods and service ranging from capital goods up to basic necessities. The positive relationship between inflation and import in this study is similar with traditional theory of inflation, and import that asserts the positive relationship between import and inflation. The finding of this study also supports the finding of Ulke and Ergun (2011), who found positive relationship between inflation and volume of import for the economy of Turkey.

In a similar manner, the study found positive significant relationship between real effective exchange rate (REER) and aggregate price level in Ethiopia during the period under examination. In other words, In the long run, impact of real effective exchange rate on consumer price index is positive and significant. The specific coefficient found from Johansen co integration test is that aggregate consumer price level rise by $1 \%$ when real effective exchange rate (EER) of ETB to dollar increase by $0.2810350 \%$. To explain it from the policy aspect, it means that any increase/appreciation of real effective exchange rate by $1 \%$ increases the inflation or the consumer price indexes by $0.2810350 \%$. This finding is consistent with the study of Vicente (2007), who found that exchange rate has positive significant relationship on domestic price level for Mozambique economy. In addition, 
it is consistent with the finding of Imrana (2013) who found very strong positive impact of real effective exchange on the economy of Pakistan. Further, the finding of this study is also similar with what Mohammednur (2012), and Gossaye (2015) found the same result when they studied exchange rate pass through to inflation, and effectiveness of devaluation in achieving internal and external balance, respectively for Ethiopian economy.

Here, there is some fact one can observe from the analysis. That is influence of IMPT and REER are closer to each other. The possible explanation for this is that imports, whatever the level of volume, are paid in terms of dollar. But when we change depreciated ETB to dollar the birr purchase few dollars and in turn few imports come to the country. This is the possible justification regarding the coefficients of IMPT (0.23970) and REER $(0.2810350)$.

\subsection{Vector Error Correction Model (The short run Dynamic Relationship between VAT and Inflation)}

Introducing and running vector error correction model for the purpose of obtaining short run relationship between VAT and inflation is to be estimated if the following steps are success full.

In the first step log of time series in the study should be found stationary in the first differences. This means that the variables should be integrated of order one.

Thus, it will be conducted to see whether the effect of VAT in the long run also appear in the short run. VECM has also many advantages as it helps to eliminate deviations from long run equilibrium through error correction term. This error correction term is also called the speed adjustment. Since there may be disequilibrium in the short run the speed of adjustment wants to eliminate this disequilibrium. In this study, the error correction model used to see short run dynamics is as follows.

$$
\begin{aligned}
\log C P I t=\alpha o+ & \sum_{i=1}^{q} \alpha 1 i \Delta \log C P I t-1+\sum_{i=1}^{q} \alpha 2 i \Delta \log F \text { DFCTt }-1+\sum_{i=1}^{q} \alpha 3 i \Delta \log R E E R t-1 \\
& +\sum_{i=1}^{q} \alpha 4 i \Delta \log V A T t-1+\sum_{i=1}^{q} \alpha 5 i \Delta \log B R D M t-1+\sum_{i=1}^{q} \alpha 6 i \Delta \log I M P T t-1+\mu E C M t \\
& -1+s t \ldots \ldots \ldots \ldots \ldots \ldots \ldots \text { (3.10) }
\end{aligned}
$$

Where, $\mu t$ shows the speed of adjustment,

$S_{t}$ Represent white noise error term

$\alpha s$ Represent short run parameters

Since variables are checked for stationary there is no any fear of spurious regression in the model. The sign and coefficient of $\boldsymbol{\mu}$ has important role in the analysis of the model. The negative and significant sign of $\boldsymbol{\mu}$ shows that there is long run causality and $\boldsymbol{\mu}$ is significant means that there is short run relationship between variables of the

\begin{tabular}{|c|c|c|c|c|}
\hline \multicolumn{5}{|c|}{ Error Correction: D(LOGCPI) } \\
\hline Variables & Coefficient & Std. Error & t-Statistic & Prob. \\
\hline Speed of Adjustment & -0.479097 & 0.173396 & -2.763026 & 0.0102 \\
\hline D(LOGCPI(-1) & 0.494961 & 0.242479 & 2.041251 & 0.0211 \\
\hline D(LOGCPI $(-2)$ & 0.207072 & 0.188696 & 1.097381 & 0.2822 \\
\hline D(LOGFDFCT $(-1)$ & 0.455126 & 163.1658 & 1.375626 & 0.1802 \\
\hline D(LOGFDFCT(-2) & -0.067432 & 120.3574 & -0.723407 & 0.4757 \\
\hline D(LOGREER(-1) & 0.903643 & 400.2433 & 2.409510 & 0.0154 \\
\hline D(LOGREER(-2) & 0.569717 & 436.3085 & 2.689769 & 0.0121 \\
\hline D(LOGBRDM(-1) & 0.110879 & 113.9535 & 2.237912 & 0.0137 \\
\hline D(LOGBRDM(-2) & 0.448129 & 119.6652 & 2.443886 & 0.0213 \\
\hline $\mathrm{D}(\mathrm{LOGVAT}(-1)$ & 0.0051101 & 0.004980 & 10.26058 & 0.0000 \\
\hline$\underline{\text { D(LOGVAT(-2) }}$ & 0.013417 & 0.012987 & 1.033076 & 0.3107 \\
\hline D(LOGIMT( -1$)$ & 0.083851 & 2379.892 & 3.354600 & 0.0024 \\
\hline D(LOGIMPT(-2) & -0.229548 & 2221.000 & -1.715547 & 0.0977 \\
\hline $\mathrm{C}$ & -32.27105 & 44.91970 & -0.718416 & 0.4787 \\
\hline
\end{tabular}
study. In other words, after the shock the short run, the speed of adjustment toward the long run is called $\mu$.

Table 9: The Result of short Run influence from Vector Error Correction Model 


\begin{tabular}{|ll|l|l|}
\hline \hline \multicolumn{2}{|l|}{ Statistical Behavior of the Model } & & \\
\hline \hline R-squared & 0.871035 & Mean dependent variable & 0.113570 \\
\hline Adjusted R-squared & 0.803856 & S.D. dependent variable & 0.930167 \\
\hline S.E. of regression & 0.191457 & Akaike info criterion & 14.07755 \\
\hline Sum squared residual & 3.269769 & Schwarz criterion & 14.66267 \\
\hline Log likelihood & 11.18575 & Hannan-Quinn criterion. & 14.29061 \\
\hline F-statistic & 13.44390 & Durbin-Watson stat & 1.992217 \\
\hline \begin{tabular}{l} 
Probability(F-statistic) \\
\hline \hline
\end{tabular}
\end{tabular}

Source: Own Computation from e-view 7.1

Conducting an error correction model has two important advantages. One is that it provides an estimated short run coefficients and the other is that it has the capacity of providing the speed of adjustment or where there is the convergence of short run dynamics to the long run. Here, the speed of adjustment from the result is 0.4790 , which is 47.9 percent implying that there is no full adjustment to long run equilibrium within two quarters. Table 4.9 shows the short run dynamic relationship between price level (inflation) and VAT for the period under examination. Thus, the VECM associates the changes in inflation to the changes in the lagged variables of value added tax.

In the short run, past quarter VAT has both positive and significant influence on the current price level in Ethiopia. This is in line with the priori expectation. However, the past two quarters have insignificant positive relationship on inflation. From table 4.9 below it can be interpreted that when the past quarter VAT (revenue) increase by 5.1 percent the inflation increases by $1 \%$ in Ethiopia. This is due to the rise in VAT revenue for the purpose of monetizing the government budget deficit and other public expenditures.

The other significant Variables in the short run are the past quarter of import (D (LOG IMPT (-1) and the past and past two quarter of real effective exchange rate. From table 4.9, if the past two quarter inflation increases by $1 \%$, the past year import will increase by 8.3 percent. In a similar manner, when the past two quarter exchange rate increases by 44 percent inflation increases by a percent. The past quarter records of fiscal deficit have positive effect on the current inflation on the inflation as expected. However, it is not significant in the short run. Broad money (M2) has also positive effect on the current inflation on the inflation as expected and, it is also significant in the short run. This result is in line with monetarists as they reasoned out it that inflation is monetary phenomena always and everywhere specially in the words of Milton Fried Man. The past quarter REER is also found to be significant in the short run. The adjusted R-squared is 0.803856 , indicating that 80.3 percentage point variation in inflation (aggregate Price level) during the period 2004Q1 to 2014Q4 in Ethiopia is explained by the explanatory variables. The estimated error correction model enjoys a high goodness fit (R-squared $=0.871035$ and adjusted R-squared $=0.803856$ )

\subsection{Model Diagnostic Tests}

No doubt, diagnostic test is the backbone of econometric analysis as it helps strength of the variable. In addition to this, for any meaning full research work, exemplification of analytical tool is very much important. Its model should be free from the fear of any spurious result. It is observed from the various test conducted for both the best regression model and the error correction model that we fail to reject the null hypotheses but rather accepted them, implying that the residuals of the model are not suffering from serial correlation; they are normally distributed and they are homoscedastic as reported by both Breusch-Pagan-Godfrey and ARCH tests respectively.

Table 10: Diagnostic test result reports for residuals of the best estimated regression model and the Error Correction Model (ECM)

\begin{tabular}{|l|l|l|l|}
\hline $\begin{array}{l}\text { Diagnostic tests } \\
\text { For Best Regression }\end{array}$ & Null hypothesis(Ho) & $\begin{array}{l}\text { Probability } \\
\text { Value }\end{array}$ & Decision (Inference ) \\
\hline BreuschGodfrey LM Test & No Serial correlation & 0.3485 & Fail to Reject Ho \\
\hline Jarque-Bera Statistics & Normally distributed & 0.932314 & Fail to Reject Ho \\
\hline Breusch-Pagan-Godfrey & Homoskedastic & 0.2315 & Fail to Reject Ho \\
\hline ARCH Diagnostic Tests for ECM & Fail to Reject Ho \\
\hline \multicolumn{2}{|c|}{ No } \\
\hline Breusch-Godfrey LM Test & No Serial correlation & 0.3294 & Fail to Reject Ho \\
\hline Jarque-Bera Statistics & Normally distributed & 0.467468 & Fail to Reject Ho \\
\hline Breusch-Pagan-Godfrey & Homoscedastic & 0.2878 & Fail to Reject Ho \\
\hline
\end{tabular}

Source: Own computation from e-view 7.1 
The lowest portion of Table 10 above shows the result of the multivariate diagnostic test of the vector error correction model. The result of the table shows that Vector error correction model (VECM) is desirable as it fulfills the requirement of the OLS model. With regard to the serial correlation the model is free from any serial correlation since the null hypothesis of no auto correlation in Breusch-Godfrey Serial Correlation cannot be rejected with the given probability of 0.2758 which is above $5 \%$ percent level of significance. Thus, it is now safe to conclude that the model does not indicate the presence of any serial correlation in the model of consumer price index. Regarding normality of the model, the Jerque Bera test of normality through Kurtosis and skewness reveals the absence of outliers in the series of the study implying normality of the model. Furthermore, the result of the normality test is supported by the Jerque Bera test value of 1.520849 with the corresponding probability of 0.467468 . This means that the null hypothesis of normality of the model cannot be rejected since the probability is greater than $5 \%$. Thus, there is sufficient evidence about the normality of the model used in the study.

Though, the heteroskedasticity is more relevant for the analysis of cross-sectional data than for

Time-series data (Vogelvang, 2005), the Breusch-Pagan-Godfrey heteroskedasticity test is conducted in this study. The null hypothesis of homoskedasticity of the model does not rejected as the probability attached to it is $(0.99)$ greater than $0.05(5 \%)$ though heteroskedasticity is not that much serious problem in time series analysis.

Fig. 1 shows the stability of the model. The stability in this study is established for the purpose of strengthening the analysis of the study. Satiability of the parameters was examined through plots from one step recursive residuals in a graphical estimate. The null hypothesis of parameter, stability, does not rejected as the plots of the recursive residual bounds within $95 \%$ critical values. This implies that parameters and coefficients of study are stable for the period of examination.

Fig.1: Model Stability from one step recursive residuals

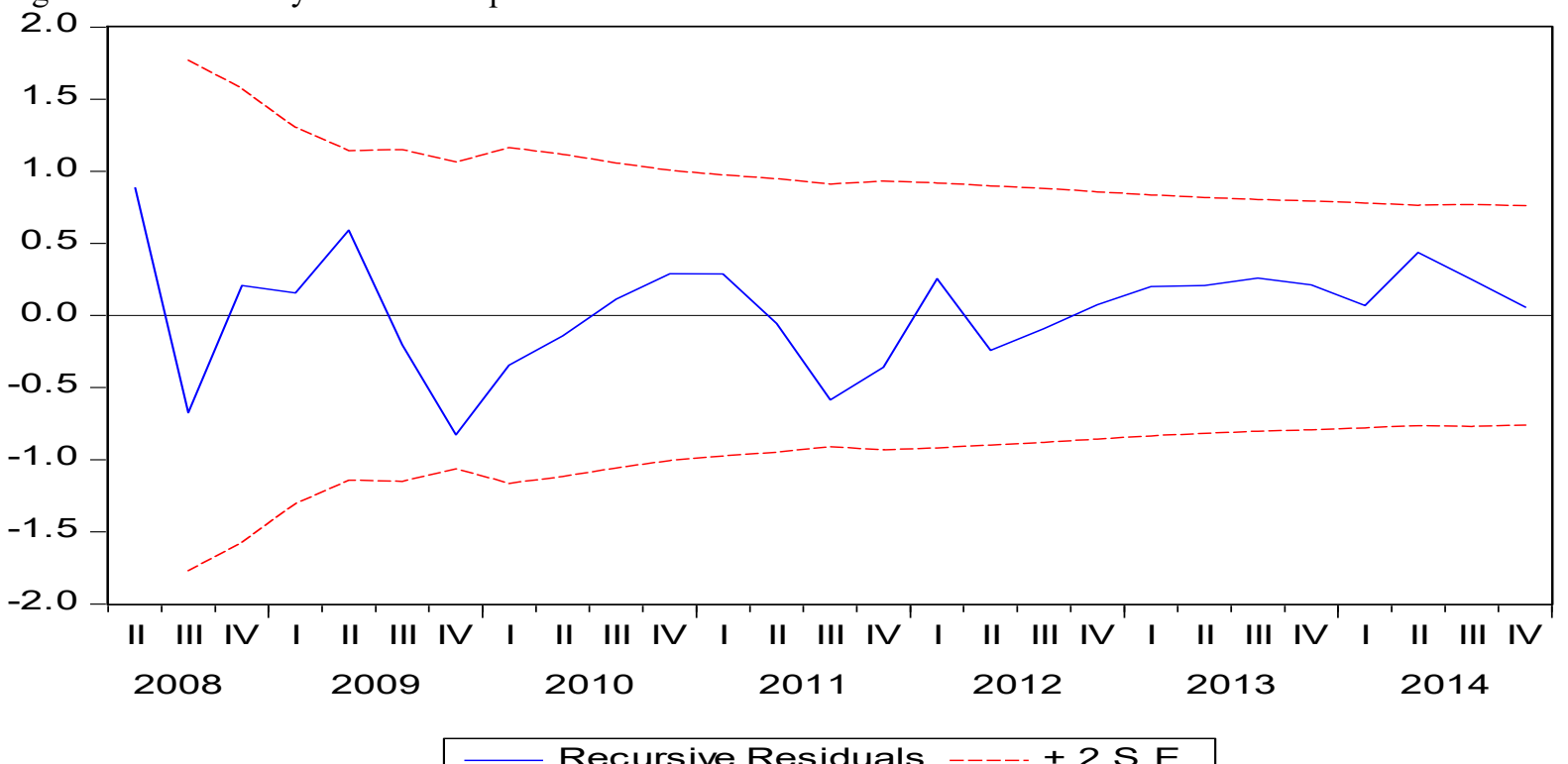

Source: Own Estimation from e-views software 7.1

\section{Conclusion and Policy Implication}

This study attempted to investigate the relationships between Value added tax (VAT) and Price level (inflation) in Ethiopia using partial equilibrium analysis of quarterly time series data over the period 2004Q1 -2014Q4. It employed 44 quarterly observations and six explanatory variables. Inflation, an explained variable of this study, is a major challenge of Ethiopian economy despite its current fast growth. Thus, dealing with the relationship between value added tax and aggregate price level in Ethiopia is, unquestionable, important since it provide a base line to forging a long term solution. Moreover, curbing inflation bolster the economic growth as it is the multifaceted macroeconomic phenomena.

The finding of this study is a witness about the complexity of general price level especially in growing economies like Ethiopia. The macroeconomic uncertainties that are associated with inflation in Ethiopia are, but not limited to VAT; real effective exchange rate; imports of goods and services, fiscal deficit and broad money. The conclusion from the finding of this study is that these independent variables jointly and significantly influenced the general level of price in Ethiopia as much as 80.3 percent while the error term captured the remaining 19.7 percent at 5 percent level of significance.

It is concluded, from the Johansen co integration, that Value added tax have a positive and significant 
relationship with inflation in Ethiopia in the long run. The finding of this study shows that the coefficient of value added tax is 0.188578 implying that a one percent increase in VAT revenue in Ethiopia ceteris paribus would lead to a 0.188578 percent increase in inflation in line with the priori expectation. In a similar manner, the coefficient for VAT is 0.00511 , meaning a one percent increase in the VAT revenue leads to a 0.00511 percent increase in inflation in the short run. Thus, it can be concluded that the relationship between VAT and inflation is positive in both short and long run. Moreover, the finding of this study revealed that the coefficient of VAT is greater in the long run when compared to the coefficient in the short run.

The strong positive relationship between VAT and general price, in both short and long run, is most likely due to multiple VAT burden exerted on individuals and corporate VAT burdens in Ethiopia. This happens through VAT charges on intermediate out puts. The other serious problem here is that it becomes very difficult to draw line between intermediate and final out puts even if they are exempted from the VAT. The conclusion inferred from this study is consistent with the conclusion drawn by Maries and Al well (2013) and Ajakaiye (1999), who concluded also that VAT strongly push up the price level. Thus, Value Added tax despite its significant contribution to the national revenue is not free from strong inflationary consequences in Ethiopia. The policy implication is that well-being of the society needs to be taken into account in the process of public revenue generation. It follows that government should assure social desirability of VAT by conducting post implementation cost benefit analysis. In addition, VAT revenue should be utilized in the way that does not significantly affect price stability in the long run since the study revealed that it is among the major variables that are influencing instability in the general price level in Ethiopia in the period under investigation.

Moreover, in order to attain price stability in Ethiopia, all fundamental factors should be taken into consideration. The finding of the study has shown that VAT is inflationary. In a similar manner, broad money (simply money supply) is also found to have inflationary consequences. The general policy implication therefore is that for effective price control in Ethiopia, both fiscal policy and monetary policy should be well coordinated. The idea is that though value added tax (VAT) is weaker than broad money when viewed from elasticity aspect the fact that it positively influence inflation suggests that stability in VAT revenue is necessary condition for stable prices in Ethiopia. It follows that ensuring fiscal stability seems to be a panacea for sustainable price stability in Ethiopia. In developing countries like Ethiopia the result from such study helps to consolidate the benefit of VAT by providing better management in the tax system.

\section{Recommending Further Studies}

There is no doubt that relationship between VAT and aggregate price level requires intensive subsequent studies as inflation affects the life of every people in day to day activities. Moreover, investigating factors affecting price level in any country is nowhere to end over a night. This is due to the fact that inflation is one of the complex phenomena that have diverse faces. In addition, in this globalized twenty first century, every country wants to have tolerable and acceptable single digit level of inflation. Thus, these conditions added together shows that there is wide room for further researchers in Ethiopia regarding this issue. Thus, further studies can include foreign aid and remittances as well as other variables that are important factor in modeling of inflation in developing economies like Ethiopia.

\section{Conflict of Interest}

In any form or shape, this piece of work has got no conflict of interest. The author has decided to work on this article in order to contribute to the body of knowledge. Thus, the article is purely a scholarly work for academic advancement.

\section{References}

Abate, M. T. (2011). Ethiopian Tax Accounting: Principles and Practice((New Revised Edition). Addis Abeba, Ethiopia.

Adereti S.A, Adesina J. A and Sanni, M.R. (2011). Value Added Tax and Economic Growth of Nigeria. European Journal of Humanities and Social Sciences, Vol. 10 (No.1 (Special Issue)), 456-471.

Adesola, S. (2000). Tax Laws and Administration in Nigeria Third revised edition. bafemi Awolowo University Press: Ile Ife.

Ajakaiye, D. O. (1999). Macroeconomic Effects of VAT in Nigeria: Acomputable General Equilibrium Analyisis. African Economic Research Consortium Research paper No. 92 (pp. 1-38). Nairobi: The African Economic Research Consortium.

Akinbobola(2012). The dynamics of money supply, exchange rate and inflation in Nigeria. Journal of Applied Finance \& Banking, 2012, vol. 2, issue 4, 8

Alemu, D. (2011). Empirical Analysis of The Contribution of Value added tax For Economic Development and Social Spending in Ethiopia (MSc Thesis). Addis Ababa University, Department of Accounting and Finance.: Addis Ababa. 
Andrew M C Smith, Ainul Islam \& M. Moniruzzaman. (2011, December). Consumption Taxes in Developing Countries, The Case of the Bangladesh VAT.Working Paper sereis,Centre for Accounting, Governance and Taxation Research Working Paper No. 82 , pp. 1-34.

Andrew M C Smith, Ainul Islam \& M. Moniruzzaman. (2011, December). Consumption Taxes in Developing Countries, The Case of the Bangladesh VAT.Working Paper sereis,Centre for Accounting, Governance and Taxation Research Working Paper No. 82, pp. 1-34.

Aruwa, S.A.S (2008) The Administration and Problems of Value added Tax in Nigeria. Finance and Accounting Research Monitor Vol.2 (2) September

Asogwa F. O. and Nkolika O. M. (2013). Value Added Tax and Investment Growth in Nigeria: Time Series Analysies. IOSR Journal Of Humanities And Social Science (IOSR-JHSS), Volume 18 (Issue 1), PP 28-31.

Bacarreza, G., Martinez-Vazquez, J., \& Vulovic. V. (2013). "Taxation and Economic Growth in Latin America. Universidad EAFIT International Center for Public Policy. Andrew Young School of Public Studies. Georgia State University, the World Bank.

Bakare AS (2013): Value Added Tax and Output Growth In Nigeria. Proceedings of $8^{\text {th }}$ Annual London Business Research Conference Imperial College, London, UK, 8-9 July

Begotic Z. and Hassan F. (1993). " Determinants of Value-Added Tax Revenue: A Cross Sectional Analysis ". World Bank Working Paper-series No.1203.

Bhartia, H. (2009). Public Finance(24th). New Delhi: Vikas Publishing House PVT Ltd.

Denbel Sharew F. , Yilkal W. and Teshome A. (January 2016). The Relationship between Inflation, Money Supply and Economic growth in Ethiopia: A Co integration and Causality Analysis. International Journal of Scientific and Research Publications, Volume 6, (Issue 1), 556-565.

Dickey, D. A. and W. A. Fuller (1979), "Distribution of the estimators for autoregres-sive time series with a unit root, "Journal of the American Statistical Association, 84, 427-431

Enders, W. (1995). Applied Econometric Time Series,. New Delhi: Wiley India Pvt. Ltd.

Everton D. V. N., Wilson E. Herbert. (September, 2012). The Relationship between Fiscal Deficits and Inflation: Econometric Evidence for Nigeria. Economics and Finance Review , , Vol. 2(7), pp. 17 - 30.

Ezeabasili V. Joseph N. Mojekwu, Wilson E. Herbert. (2012). An Empirical Analysis of Fiscal Deficits and Inflation in Nigeria. International Business and Management, Vol. 4 ( No. 1), pp. 105-120.

Ezeji E. C. and Peter I. (2014). Econometric Analysis of the Impact of Value Added Tax on Economic Growth in Nigeria. European Journal of Business and Management, Vol.6 (No.18), 31-36.

Fatukasi, B. (2005). Determinants of Inflation in Nigeria: An Empirical Analysis. International Journal of Humanities and Social Science, Vol. 1 (No. 18), 262-271.

Federal Democratic Republic of Ethiopia. (2002). Council of Ministers Value Added Tax Regulations No. 79/2002. Federal Negarit Gazeta, 9th year, No. 19 , pp. 1979-2010,Addis Ababa ,Ethiopia.

Gatawa M.N, Haruna M. Aishatu (2013): Evaluating the impact of value added tax on the economic growth of Nigeria, Journal of accounting and Taxation, Full Length Research Paper. Vol. 8(6), pp. 59-65, November, 2016. ISSN 2141-6664

Gujarati, D.N. and Porter, D.C. (2009). Basic Econometrics (5th ed.), ,. New York: NY: McGraw Hill publishing .

Gossaye, T. (2015). Effectiveness of Devaluation in Achieving Internal and External Balance: The Case of Ethiopia. Un published Masters thesis, Addis Ababa University, Addis Ababa.

Hassan, B. (2015). The Role of Value Added Tax (VAT) in the Economic Growth of Pakistan. Journal of Economics and Sustainable Development, Vol.6, ( No.13,), 174-183.

Imrana Asad Nisar Ahmad Zakir Hussain. (2013). Impact of Real Effective Exchange Rate on Inflation on Pakistan. Asian Economic and Financial Review , 2 (8), 983-990.

Ilaboya O.J and Magbame C.O. (2012). Indirect Tax and Economic Growth. Research Journal of Finance and Accounting, 3 (11), 70-82.

Izedonmi F. I. and . OkunborJ. A. (2014). The Roles of Value Added Tax in the Economic Growth of Nigeria. British Journal of Economics, Management \& Trade, 4 (12), 1999-2007.

Jalata, D. M. (2014). The Role of Value Added Tax on Economic Growth of Ethiopia. Science, Technology and Arts Research Journal, Vol.3 (No.1), 156-161.

Johansen, S. (1995). Likelihood-based inference in cointegrated vector autoregressive models. Oxford Bulletin of Economics and Statistics , , 52, 169-210.

Johansen, S. (1988). Statistical analysis of cointegration vectors. Journal of Economic Dynamics and Control , 12 , 231-254.

Maddala. (1992). Introduction to Econometrics,. New York.: MACMILLAN Publishing Company.

Makochekanwa, A. .. (2011). Impact of Budget Deficit on Inflation In Zimbabwe. The economic research Guardian, 1 (2), 49-59.

Marius I. and Alwell N.(2013). Value Added tax and price stablity in Nigeria. European Journal of Government and Economics, 2 (2), 137-147. 
Michael, K and Ben, L. (2007). The Value-Added Tax: Its Causes and Consequences. Working Paper 183. IMF.

MacKinnon, J. G., A. A. Haug, and L. Michelis (1999), "Numerical distribution functions of likelihood ratio tests for integration," Journal of Applied Econometrics, 14, 563-577.

Musa and Sanusi (2013), Analyzing the Impact of Value Added Tax (VAT) on Economic Growth in Nigeria, Mathematical Theory and Modeling.Vol.3, No.14, 2013. ISSN 2225-0522 (Online)

Mohammednur, B. (2012). Exchange Rate Pass through in Ethiopia. unpublished Masters Thesis Report,Addis Abeba University, Addis Abeba, Ethiopia.

Owino (2019), An Empirical Analysis of Value Added Tax on Economic Growth, Evidence from Kenya Data Set. Journal of Economics, management and trade, 22(3): 1-14, 2019; Article no.JEMT.46167. ISSN: 2456-9216.

Okoye, E.I \& Gbegi, D.O. (Year 2013). Effective Value Added Tax: An Imperative for Wealth Creation in Nigeria. Global Journal of Management and Business Research, Volume 13 (Issue 1 Version 1.0 ,Double Blind Peer Reviewed International Research Journal), 91-99.

Olatunji, O. C. (2009). A Review of Value Added Tax( VAT) in Nigeria. International Business Managment, 3 (4), 61-68.

Simon Tareke, Yibrah Hagos, Abiy Kassa. (2013). Problems and Prospects of Value-Added Tax (VAT) Implementation in Tigrai Regional State. Vol. 1 | No. 1 , Vol. 1 (| No. 1), 1-16.

Ulke V. and Ergun U. (2011). Econometric Analysis of Import and Inflation Relationship in Turkey between 1995 and 2010. Journal of Economic and Social Studies, Volume 1 (Number 2), 69- 81.

Umeora, C.E (2013). The Effects of Value Added Tax (VAT) on the Economic Growth of Nigeria, Journal of Economics and Sustainable Development, Vol.4 (6)

Vicente, C. (2007). Exchange rate and Consumer Prices in Mozambique: A Cointegration Approach. Conference Paper no. 40, (pp. 1-23).

Vogelvang, B. (2005). Econometrics. In Theory and Applications with EViews. Pearson Education Limited. 